\title{
AIDS-related Kaposi's sarcoma: outcomes after initiation of highly active antiretroviral therapy under routine conditions in Zimbabwe
}

\author{
Bradley Nelson ${ }^{*}$, Margaret Borok², Tariro Makadzange², Tafadzwa Mhlanga², Thomas Campbell ${ }^{1}$ \\ From $12^{\text {th }}$ International Conference on Malignancies in AIDS and Other Acquired Immunodeficiencies \\ (ICMAOI) \\ Bethesda, MD, USA. 26-27 April, 2010
}

\section{Background}

Additional information on the outcomes of patients with AIDS-related Kaposi's sarcoma (AIDS-KS) on highly active antiretroviral therapy (HAART) in resource-limited settings is needed. This study evaluated outcomes in AIDS-KS patients after initiation of HAART in Zimbabwe.

\section{Methods}

A retrospective cohort of 124 patients from the Parirenyatwa Hospital Kaposi's Sarcoma and Opportunistic Infections (OI) Clinics was studied. 31 patients with AIDS-KS were matched 1:3 to 93 non-KS AIDS patients based on date of initiation of HAART, gender, and age. The primary endpoint was loss to care, defined as failure to attend clinic or refill prescriptions for 3 months or longer. Secondary endpoints were weight gain at 6 months, change in CD4+ count within 1 year, and final CD4+ count within 1 year of initiating HAART. Eligibility criteria included a minimum of 6 months of followup in the OI Clinic and less than 2 months of previous HAART prior to beginning therapy through the OI Clinic. A two-step model-selection strategy using KS status, gender, age, WHO performance status, OI disease burden, medical aid, employment, education, pretreatment cotrimoxazole use, pre-treatment weight, and pre-treatment CD4+ count was used to identify factors associated with loss to care. On the initial univariate analysis, KS status, medical aid, and pre-treatment cotrimoxazole use had a $\mathrm{p}<0.15$ and were included in the final multivariate analysis.

\footnotetext{
* Correspondence: bradley.nelson@ucdenver.edu

'Department of Medicine, University of Colorado, Denver, Aurora, CO, USA Full list of author information is available at the end of the article
}

\section{Results}

AIDS-KS and non-KS patients did not differ significantly in baseline characteristics except for pre-treatment CD $4+$ count (196 vs. 92 cells $\left./ \mathrm{mm}^{3}, \mathrm{p}=0.005\right)$. On the multivariate analysis, KS status ( $\mathrm{p}=0.016, \mathrm{HR}$ : $4.11, \mathrm{CI}$ : 1.31-12.92) and having medical aid were significant predictors of loss to care $(\mathrm{p}=0.048$, HR: 3.84 , CI: 1.02 14.44). At a median followup of 632 days, $37.5 \%$ of AIDS-KS patients were lost to care compared to $16.1 \%$ of non-KS patients. AIDS-KS patients had significantly worse weight gain than non-KS patients $(+0.78 \%$ vs. $+4.18 \%, \mathrm{p}=0.023)$. Change in $\mathrm{CD} 4+$ count $(\mathrm{p}=0.149)$ and final $C D 4+$ count $(p=0.729)$ were not significantly different between study groups. Amongst AIDS-KS patients, retained patients $(n=20)$ had significantly higher pre-treatment $\mathrm{CD} 4+$ counts than patients lost to care $(\mathrm{n}=11)\left(232\right.$ vs. 122 cells $\left./ \mathrm{mm}^{3}, \mathrm{p}=0.048\right)$.

\section{Conclusions}

After initiating HAART, AIDS-KS patients experienced greater loss to care and poorer weight gain than matched non-KS patients, suggesting that, under routine conditions in Zimbabwe, AIDS-KS patients have worse intermediate- and long-term clinical outcomes than non-KS AIDS patients. AIDS-KS patients retained in care had higher pre-treatment CD4+ counts than patients lost to care, indicating that early intervention with HAART may improve outcomes in AIDS-KS patients.

\section{Acknowledgements}

This article has been published as part of Infectious Agents and Cancer Volume 5 Supplement 1, 2010: Proceedings of the $12^{\text {th }}$ International Conference on Malignancies in AIDS and Other Acquired 
Immunodeficiencies (ICMAOI). The full contents of the supplement are available online at http://www.biomedcentral.com/1750-9378/5?issue=S1

\section{Author details}

'Department of Medicine, University of Colorado, Denver, Aurora, CO, USA.

${ }^{2}$ Department of Medicine, University of Zimbabwe, Harare, Zimbabwe.

Published: 11 October 2010

doi:10.1186/1750-9378-5-S1-A2

Cite this article as: Nelson et al:: AIDS-related Kaposi's sarcoma:

outcomes after initiation of highly active antiretroviral therapy under

routine conditions in Zimbabwe. Infectious Agents and Cancer 2010

5(Suppl 1):A2.

Submit your next manuscript to BioMed Central and take full advantage of:

- Convenient online submission

- Thorough peer review

- No space constraints or color figure charges

- Immediate publication on acceptance

- Inclusion in PubMed, CAS, Scopus and Google Scholar

- Research which is freely available for redistribution

Submit your manuscript at www.biomedcentral.com/submit 